\title{
New genus of subfamily Cypridopsinae Kaufmann, 1933 (Crustacea: Ostracoda) from Thailand
}

\author{
Sukonthip SAVATENALINTON \\ Department of Biology, Plant and Invertebrate Taxonomy and its Applications Research Unit, \\ Faculty of Science, Mahasarakham University, Maha Sarakham 44150, Thailand. \\ Email: sukonthip.s@msu.ac.th
}

urn:1sid:zoobank.org:author:254994A1-C8E1-4242-ADF8-184661366B2D

\begin{abstract}
The new genus Thaicypridopsis gen. nov. described here belongs to the tribe Zonocypridini Higuti \& Martens, 2012 in the subfamily Cypridopsinae Kaufmann, 1900. It is the first record of the Recent representatives within this tribe in Southeast Asia and Oriental regions. Thaicypridopsis gen. nov. has a number of remarkable characters that distinguish it from other genera in the subfamily: a submarginal row of distinctive tubercles on the postero-ventral part of the right valve in the interior view, a strong serrated claw G2 on the second antenna with an apical concavity, large bristles with hirsute endings and spatula-shaped apexes on all three maxillular endites and a bifurcate tip on the terminal claw of the second thoracopod. One new species, Thaicypridopsis longispinosa sp. nov., is described under this new genus in the present contribution. Apart from the above diagnostic characters, the new species also has long spines on the valve surface as its outstanding feature. The new taxon is morphologically compared with other related species and genera within and outside the subfamily Cypridopsinae. In addition, due to the new genus belonging to a group of genera with the left valve overlapping the right valve in the subfamily, a key to the genera within this group is given.
\end{abstract}

Keywords. Oncocypridinae, microcrustacean, taxonomy, diversity, Southeast Asia.

Savatenalinton S. 2018. New genus of subfamily Cypridopsinae Kaufmann, 1933 (Crustacea: Ostracoda) from Thailand. European Journal of Taxonomy 487: 1-17. https://doi.org/10.5852/ejt.2018.487

\section{Introduction}

Cypridopsinae Kaufmann, 1900 which, is the most diverse subfamily in the family Cyprididae Baird, 1845, is presently composed of 18 genera: Austrocypridopsis McKenzie, 1982; Bryocypris Røen, 1956; Cabelodopsis Higuti \& Martens, 2012; Cavernocypris Hartmann, 1964; Cypridopsis Brady, 1867; Kapcypridopsis McKenzie, 1977; Klieopsis Martens et al. 1991; Martenscypridopsis Karanovic, 2000; Neocypridopsis Klie, 1940; Plesiocypridopsis Rome, 1965; Potamocypris Brady, 1870; Pseodocypridopsis Karanovic, 1999; Sarscypridopsis McKenzie, 1977; Siamopsis Savatenalinton, 2017; Tanganyikacypridopsis Martens, 1985; Thermopsis Külköylüoğlu et al., 2003; Tungucypridopsis Victor \& Fernando, 1983; and Zonocypris Müller, 1898 (Martens \& Savatenalinton 2011; Higuti \& Martens 2012; Savatenalinton 2017). However, the taxonomic position of the genus Neocypridopsis is contentious as some authors have placed it in the subfamily Cypridopsinae (e.g., Martens \& 
Savatenalinton 2011; Higuti \& Martens 2012), while others (e.g., Karanovic 2012) have defined it as a genus in the subfamily Oncocypridinae (family Notodromadidae). There are three tribes within the Cypridopsinae: Potamocypridini (Ghetti \& McKenzie, 1981), Zonocypridini Higuti \& Martens, 2012 and Cypridopsini Kaufmann, 1900 (Higuti \& Martens 2012). Only the genus Potamocypris belongs to the tribe Potamocypridini and the members of the tribe Zonocypridini are Cabelodopsis and Zonocypris while the tribe Cypridopsini occupies the largest fraction (the remaining genera). In the Cypridopsinae, six genera are monospecific, four of which are endemic to their specific area. On the contrary, Cypridopsis is the dominant group with c. 77 species and is widely distributed in many zoogeographical regions (Martens \& Savatenalinton 2011). The original descriptions of many cypridopsine species were incomplete and even questionable in some features, resulting in incorrect morphological comparisons and taxonomic positions. Recently, the reexamination of Zonocypris hispida (Sars, 1901) based on new material from Brazil revealed that this species is quite different from other cypridopsine taxa, hence a new genus, Cabelodopsis, was erected for it (Higuti \& Martens 2012). This is merely an example to show that a revision is needed in the subfamily. In addition, newly surveyed materials from poorly studied areas also harbored taxa, such as the genus Siamopsis with five species, which were recently described from Thailand (Savatenalinton 2017). There seems to be no doubt that there is an underestimation of the exact number of species in the Cypridopsinae. Thus far, six cypridopsine species have been recorded in Thailand (Savatenalinton \& Suttajit 2016; Savatenalinton, 2017). In the present work, one new genus based on one new species belonging to the tribe Zonocypridini of the subfamily Cypridopsinae is described from Thailand.

\section{Material and methods}

Sample collections were obtained from several types of water body in the central, northern and northeastern parts of Thailand during the period 2005-2011. In total, 293 localities were examined: 3, 54 and 236 localities from the central, northern and northeastern parts, respectively. Samples were taken with a hand net (mesh size $200 \mu \mathrm{m}$ ), preserved in 70\% ethanol and later sorted using an Olympus SZ-PT stereo microscope. Soft parts were dissected in glycerine and sealed on glass slides. Valves were stored dry on micropalaeontological slides. Drawings of the soft parts were made with the aid of a camera lucida. Carapaces and valves were observed and illustrated using a Scanning Electron Microscope (JEOL JSM6460LV - at the Faculty of Science, Mahasarakham University (MSU)). The chaetotaxy of the limbs follows the model proposed by Broodbakker \& Danielopol (1982), revised for the A2 by Martens (1987) and for the thoracopods by Meisch (2000). All type materials of the species were deposited in the Natural History Museum. Non-type material is catalogued by its collection locality and held in the author's personal collection.

\section{Institutional abbreviations}

$\begin{aligned} \text { MSU }= & \text { Mahasarakham University, Maha Sarakham, Thailand } \\ \text { MSU-ZOC = } & \text { Ostracod Collection of the Natural History Museum, } \\ & \text { Mahasarakham University, Maha Sarakham, Thailand }\end{aligned}$

\section{Abbreviations used in material citations}

$\begin{array}{ll}\mathrm{N} & =\text { Northern part of Thailand } \\ \mathrm{NE} & =\text { Northeastern part of Thailand } \\ \mathrm{NE} \text { (with numbers) } & =\text { Ostracod samples collected from southern part of Northeast Thailand } \\ \mathrm{NEE} & =\text { Ostracod samples collected from eastern part of Northeast Thailand } \\ \mathrm{NEN} & =\text { Ostracod samples collected from northern part of Northeast Thailand } \\ \mathrm{TH} & =\text { Ostracod samples collected from Northern Thailand }\end{array}$




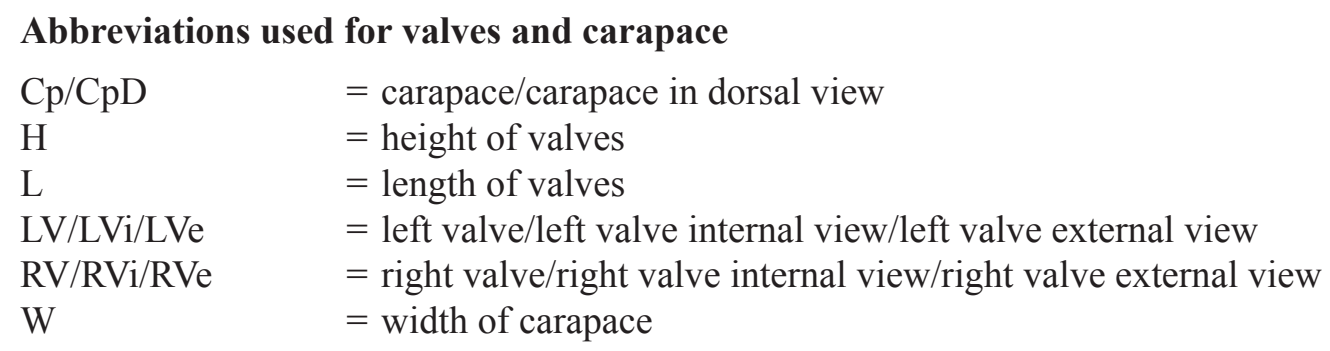

\section{Abbreviations used for limbs}

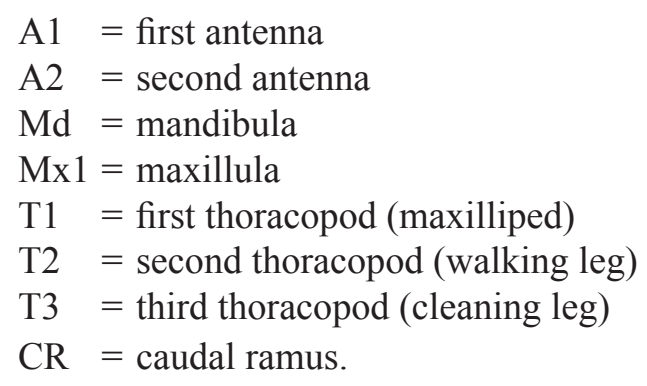

\section{Results}

Class Ostracoda Latreille, 1802

Subclass Podocopa G.O. Sars, 1866

Order Podocopida G.O. Sars, 1866

Suborder Cypridocopina Jones, 1901

Superfamily Cypridoidea Baird, 1845

Family Cyprididae Baird, 1845

Subfamily Cypridopsinae Kaufmann, 1900

Tribe Zonocypridini Higuti \& Martens, 2012

Thaicypridopsis gen. nov. urn:lsid:zoobank.org:act:9B2D9515-8CE7-4C39-B458-2F9BE057599A

\section{Type species}

Thaicypridopsis longispinosa gen. et sp. nov. (here designated).

\section{Etymology}

The genus is named after the country, Thailand, where the new taxon was discovered. The name is a combination between the abbreviated country name ("Thai") and the existing generic name "cypridopsis".

\section{Diagnosis}

LV overlapping RV. RVi with a row of distinctive submarginal tubercles on postero-ventral part. Valve surface with shallow pitted setae and/or spines. A2 with one strong serrated claw G2. Largest seta on terminal segment of Md-palp apically equipped with hairs. Terminal segment of Mx1-palp cylindrical and elongated, largest setae (bristles) on all three endites with hirsute endings and spatula-shaped apexes. Seta $\mathrm{d} 2$ on $\mathrm{T} 2$ present (d1 absent), terminal claw with bifurcate ending. Terminal segment of T3 with apical pincer. Caudal ramus reduced, flagellum-like with triangular base. 


\section{Differential diagnosis}

Thaicypridopsis gen. nov. is generally similar to Zonocypris and Cabelodopsis due to the presence of a strong serrated claw G2 on the A2. It can be distinguished from the other genera of the subfamily Cypridopsinae by the morphology of the RV in the interior view, which appears as a submarginal row of distinctive tubercles on the postero-ventral part, the presence of the robust claw on the terminal segment of the Md-palp, which is apically equipped with hairs, the presence of large bristles with hirsute endings and spatula-shaped apexes on the first to the third Mx1endites and the slightly bifurcated ending of the terminal claw of the T2. These features are diagnostic characters of the new genus and the combination of these aspects has not yet been noted in any other genus of the Cypridopsinae.

\section{Distribution}

Thailand (present study).

Thaicypridopsis longispinosa gen. et sp. nov. urn:lsid:zoobank.org:act:8C42600E-3232-40EF-BC77-765E1CC15953

Figs $1-4$

\section{Etymology}

The specific epithet 'longispinosa' refers to the outstanding appearance of long spines on valve surface. This is the most prominent character of the new species and can be easily recognized from external morphology.

\section{Type material}

\section{Holotype}

THAILAND - Buriram Province (NE) • $q$ (soft parts dissected in glycerine on a sealed glass slide and valves stored dry on a micropalaeontological slide); Huai Jorakae Mak (reservoir), Muang district; $14^{\circ} 54^{\prime} 41^{\prime \prime} \mathrm{N}, 103^{\circ} 03^{\prime} 07^{\prime \prime} \mathrm{E}$; 4 Oct. 2010; MSU-ZOC.257.

\section{Paratypes}

THAILAND - Buriram Province (NE) • $3 q q$ (stored as the holotype); same locality as for holotype; 4 Oct. 2010; MSU-ZOC.258, 261 to $262 \cdot 2$ 우 (stored as the holotype); Kwan Phayao (lake); 6 Oct. 2007; MSU-ZOC.263 to $264 \cdot 2$ 우 (carapaces stored dry on micropalaeontological slides); same locality as for holotype; 4 Oct. 2007; MSU.ZOC.259 to $260 \bullet 1$ (carapace stored dry on micropalaeontological slide); Kwan Phayao (lake); 6 Oct. 2007; MSU.ZOC.265 9 q $q$ (in 70\% ethanol); same locality as for holotype; 4 Oct. 2010; MSU.ZOC.266.

\section{Type locality}

A total of 15 female specimens ( 1 holotype, 14 paratypes) were collected at the type locality on 4 Oct. 2010 and 3 female specimens (in 70\% ethanol) were collected at the type locality on 8 Feb. 2011. Accompanying ostracod fauna (4 Oct. 2010): Alicenula sp., Bradleystrandesia weberi (Moniez, 1892), Bradleytriebella lineata (Victor \& Fernando, 1981), Cypretta sp.1, Cypretta sp.2, Cypridopsine sp., Dentocypria chantaranothaii Savatenalinton, 2017, Metacypris srisumonae (Savatenalinton et al., 2008), Pseudocypretta maculata Klie, 1932, Pseudostrandesia mamarilorum (Victor \& Fernando, 1981), Pseudostrandesia striatoreticulata (Klie, 1932), Stenocypris sp., Strandesia hornei Savatenalinton \& Martens, 2010, Strandesia kraepelini (Müller, 1906); accompanying ostracod fauna (8 Feb. 2011): Cypretta sp.1, Cypretta sp.2, Cypridopsine sp., Bradleystrandesia weberi, Pseudocypretta maculata, Pseudostrandesia mamarilorum, Pseudostrandesia striatoreticulata, Stenocypris sp., Strandesia kraepelini. 


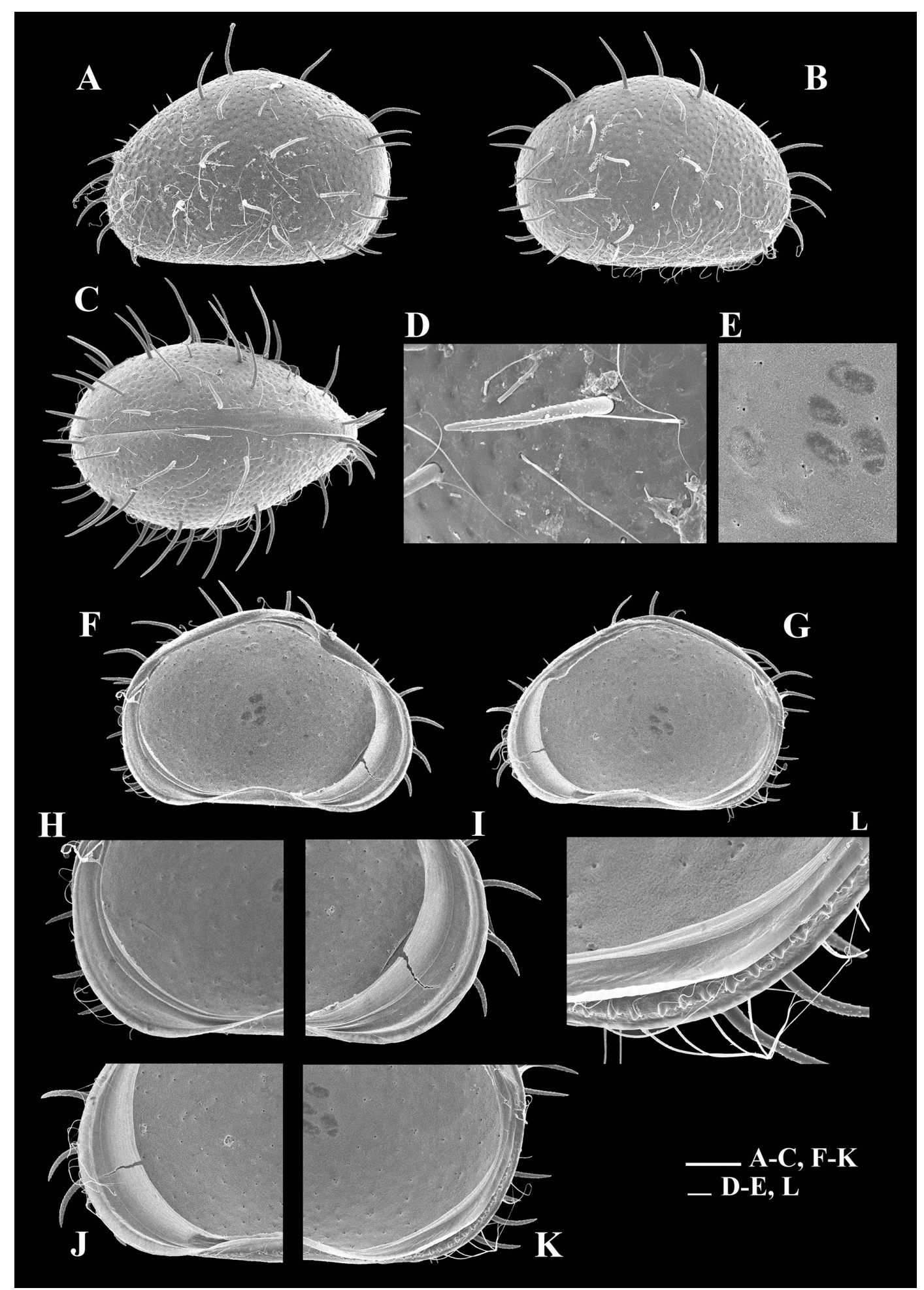

Fig. 1. Thaicypridopsis longispinosa sp. nov., 우. A. LVe (MSU-ZOC.257). B. RVe (idem). C. CpD (MSU-ZOC.259). D. Valve surface (MSU-ZOC.257). E. Muscle scars of RV (MSU-ZOC.258). F. LVi (idem). G. RVi (idem). H. Posterior part of LVi (idem). I. Anterior part of LVi (idem). J. Anterior part of RVi (idem). K-L. Posterior part of RVi (idem). Scale bars: A-C, F-G = $100 \mu \mathrm{m}$; D, L = $10 \mu \mathrm{m}$; E = $13 \mu \mathrm{m} ; \mathrm{H}-\mathrm{K}=58 \mu \mathrm{m}$. 


\section{Other material examined}

THAILAND - Phayao Province (N) - 7 + 9 ; locality 1; Kwan Phayao (lake), Muang District; $19^{\circ} 09^{\prime} 33^{\prime \prime}$ N, 99 $54^{\prime} 36^{\prime \prime}$ E; 6 Oct. 2007; accompanying ostracod fauna: Astenocypris papyracea (Sars, 1903), Bradleystrandesia weberi, Bradleytriebella lineata, Cypretta sp., Cypridopsis vidua, Cypridopsine sp., Cypris subglobosa Sowerby, 1840, Dentocypria smithi Savatenalinton, 2017, Pseudostrandesia calapanensis (Tressler, 1937), Pseudostrandesia mamarilorum, Stenocypris malayaica Victor \& Fernando, 1981, Strandesia kraepelini, Tanycypris siamensis Savatenalinton \& Martens, 2009; TH142. - Roi-Et Province (NE) - 19 우; locality 2; Lam Phayom (reservoir); 16 16'17" N, 10359'46" E; 25 Oct. and 20 Feb. 2010; accompanying ostracod fauna: Bradleystrandesia weberi, Bradleytriebella lineata, Cypridopsine sp., Dentocypria aequiloba, Dentocypria chantaranothaii, Limnocythere sp., Pseudocypretta maculata, Pseudostrandesia thailandensis Savatenalinton \& Martens, 2010, Stenocypris derupta Vávra, 1906, Strandesia kraepelini, Strandesia sexpunctata Klie, 1932, Strandesia sp.; NE067. - Chaiyaphum Province (NE) - 5 o $o$; locality 3; Nong PagPung (swamp), Phu Kiew District; $16^{\circ} 22^{\prime} 27^{\prime \prime}$ N, 102 $08^{\prime} 02^{\prime \prime}$ E; 30 Oct. 2010; accompanying ostracod fauna: Candona sp., Cypridopsine sp., Dentocypria aequiloba, Pseudocypretta maculata, Stenocypris sp., Strandesia kraepelini, Strandesia sexpunctata; NE073. - Chaiyaphum Province (NE) • 2 o 9 ; locality 4; Nong Sammuen (swamp), Phu Kiew District; 16 $24^{\prime} 27^{\prime \prime}$ N, 102 $02^{\prime} 02^{\prime \prime}$ E; 30 Oct. 2010; accompanying ostracod fauna: Metacypris srisumonae, Alicenula sp., Bradleystrandesia weberi, Cypretta sp., Dentocypria aequiloba, Dentocypria chantaranothaii, Pseudostrandesia mamarilorum, Strandesia kraepelini, Strandesia sexpunctata; NE074. - Chaiyaphum Province (NE) - 2 o $O$; locality 5; Lam Nam Kam (rivulet), Muang; 1546 $37^{\prime \prime}$ N, 102 ${ }^{\circ} 13^{\prime} 18^{\prime \prime}$ E; 3 Oct. 2010; accompanying ostracod fauna: Bradleystrandesia weberi, Chrissia sp., Cypretta sp. 2, Cypridopsis vidua, Cypridopsine sp., Dentocypria aequiloba, Dentocypria chantaranothaii, Pseudocypretta maculata, Pseudostrandesia gaetani Savatenalinton \& Martens, 2010, Pseudostrandesia mamarilorum, Strandesia kraepelini, Strandesia sexpunctata; NE007. - Chaiyaphum Province (NE) - 2 o $\circ$; locality 6; Huai Pao (river), Kaset Sombun District, $16^{\circ} 23^{\prime} 03^{\prime \prime}$ N, 101 $58^{\prime} 47^{\prime \prime}$ E; 9 Oct. 2007; accompanying ostracod fauna: Cypretta sp., Cypris subglobosa, Dentocypria chantaranothaii, Dentocypria smithi, Dolerocypris sisaketensis Savatenalinton \& Suttajit, 2016, Pseudostrandesia mamarilorum (Victor \& Fernando, 1981), Strandesia kraepelini (Müller, 1906), Strandesia sexpunctata Klie, 1932; TH152. - Ubon Ratchathani Province (NE) - 2 우; locality 7; Kang Sapue (river), Phiboon Mangsahan District; $15^{\circ} 14^{\prime} 37^{\prime \prime} \mathrm{N}, 105^{\circ} 14^{\prime} 37^{\prime \prime} \mathrm{E}$; 24 Oct. 2010; accompanying ostracod fauna: Chrissia sp., Cypridopsine sp., Pseudocypretta maculata, Pseudostrandesia calapaensis (Tressler, 1937), Pseudostrandesia gaetani, Strandesia kraepelini, Strandesia sexpunctata; NE057. - Buriram Province (NE) • 2 q $q$; locality 8; Chon Pratan Reservoir, Lampaimas District; $15^{\circ} 01^{\prime} 05^{\prime \prime}$ N, 102 $2^{\circ} 0^{\prime} 29^{\prime \prime}$ E; 8 Feb. 2011; accompanying ostracod fauna: Bradleystrandesia weberi, Dentocypria aequiloba, Pseudostrandesia thailandensis, Stenocypris derupta, Stenocypris sp., Strandesia kraepelini; NE094. - Udon Thani Province (NE)

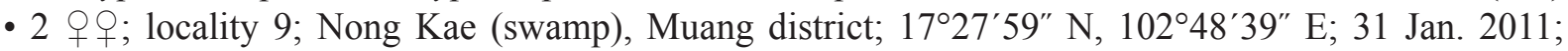
accompanying ostracod fauna: Alicenula sp., Bradleystrandesia weberi, Chrissia sp., Cypretta sp., Cypridopsis vidua, Cypridopsine sp., Dentocypria aequiloba, Fabaeformiscandona sp., Metacypris srisumonae, Pseudocypretta maculata, Pseudostrandesia mamarilorum, Stenocypris derupta, Stenocypris sp., Strandesia hornei, Strandesia kraepelini; NEN029. - Udon Thani Province (NE) -

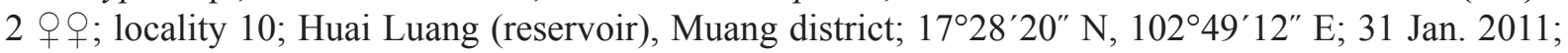
accompanying ostracod fauna: Alicenula sp., Chrissia sp., Cypretta sp. 1, Cypretta sp. 2, Dentocypria aequiloba, Pseudocypretta maculata, Strandesia kraepelini; NEN030. - Mukdahan Province (NE)

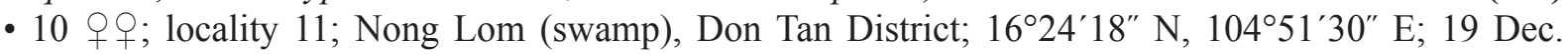
2011; accompanying ostracod fauna: Cypridopsis vidua, Cypridopsine sp., Dentocypria aequiloba, Dolerocypris sp., Ilyocypris sp., Limnocythere sp., Pseudocypretta maculata, Strandesia kraepelini, Strandesia perakensis, Strandesia sexpunctata; NEE003. 


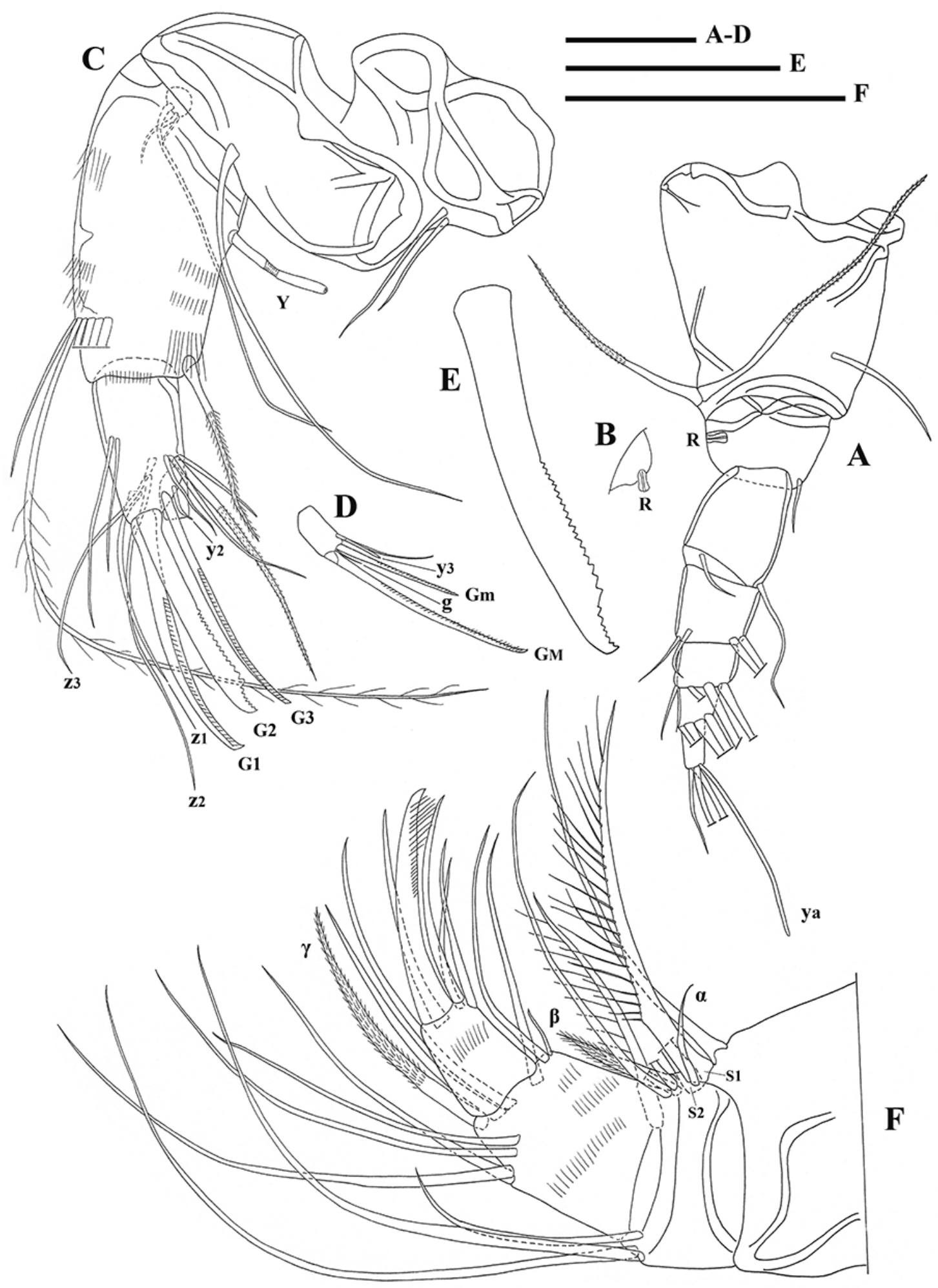

Fig. 2. Thaicypridopsis longispinosa sp. nov., $q$ + . A. A1 (MSU-ZOC.264). B. Rome organ of A1 (MSU-ZOC.257). C. A2 (idem). D. Distal segment of A2 (idem). E. Claw G2 of A2 (idem). F. Md-palp (MSU-ZOC.263). Scale bars: $50 \mu \mathrm{m}$. 


\section{Diagnosis}

$\mathrm{Cp}$ in lateral view subovate (length c. 1.5 times height) with maximum height situated at mid-length, anterior and posterior ends subequally rounded. $\mathrm{CpD}$ elliptical with maximum width situated slightly behind mid-length. LV overlapping RV all free margins. LV posterior part with double inner list, appearing well developed, but not oblique. RVi with a submarginal row of distinctive tubercles (c. 18-20 tubercles) on postero-ventral part. Valve surface equipped with shallow pitted, dispersedly long setae and markedly long spines. Claw G2 on A2 strongly serrated with apical concavity, natatory setae long (far beyond end of terminal claw), four t-setae present in females with one seta claw-like appearance. Robust claw on Md-palp terminal segment with apical group of hairs. Terminal segment of Mx1-palp cylindrical and elongated, large bristles on three endites claw-like with hirsute endings and spatulashaped apexes, number of large bristles on first to third endite being 1, 1, 2, respectively. T1 with two a-setae (b-, c- and d-setae absent). Seta $\mathrm{d} 2$ on T2 present (d1 absent), terminal claw with slightly bifurcate ending. CR reduced, flagellum-like with triangular base.

\section{Differential diagnosis}

As Thaicypridopsis gen. nov. is a monospecific genus, the new species is compared with related species in other genera within the Cypridopsinae (also see Discussion below). The new species is superficially similar to Cabelodopsis hispida (Sars, 1901) Higuti \& Martens, 2012 and Zonocypris costata (Vávra, 1897) due to the presence of a strongly serrated claw G2 on the A2 and of the tubercles on the posteroventral part of the RVi. The new species can be distinguished mainly by the robust apical claw on the terminal segment of the Md-palp with hairy ending (smooth and pointed endings in C. hispida and $Z$. costata), the morphology of the large bristles on three Mx1-endites, which appear as hirsute endings and spatula-shaped apexes, and the presence of a bifurcated tip on the T2 terminal claw (smooth tip in C. hispida and Z. costata).

\section{Measurements (in $\mu \mathrm{m}$ )}

Cp ( $\mathrm{n}=2), \mathrm{L}=528-584, \mathrm{~W}=334-378 ; \mathrm{LV}(\mathrm{n}=3), \mathrm{L}=534-588, \mathrm{H}=349-408 ; \mathrm{RV}(\mathrm{n}=3), \mathrm{L}=507-578$, $\mathrm{H}=346-397$.

\section{Description}

\section{Female}

Cp IN LATERAL VIEW. Subtriangular, anterior margin rounded, posterior margin slightly wider rounded, dorsal margin strongly arched, greatest height situated at mid-length, LV overlapping RV all free margins, valve surface pitted and equipped with setae and long spines (Fig. 1A-B), surface of long spines slightly serrated (Fig. 1D).

$\mathrm{CPD}$ (Fig. 1C). Subovate with evenly curved lateral margins, greatest width situated slightly behind midlength, posterior extremity round, anterior extremity more pointed.

LVI (Fig. 1F, H-I). Both anterior and posterior margins subequally rounded, ventral margin sinuous at mid-length, submarginal selvage anteriorly, anterior calcified inner lamella wide with two inner lists, posterior calcified inner lamella narrow with double inner list being well developed but not oblique, postero-ventral part with submarginal shallow sockets or pits (conforming to tubercles on RV).

RVI (Fig. 1E, G, J-L). Both anterior and posterior margins subequally rounded, ventral margin sinuous at mid-length, submarginal selvage anteriorly, anterior calcified inner lamella wide, posterior calcified inner lamella narrow with two inner lists, postero-ventral part with c. 18-20 prominent tubercles. 


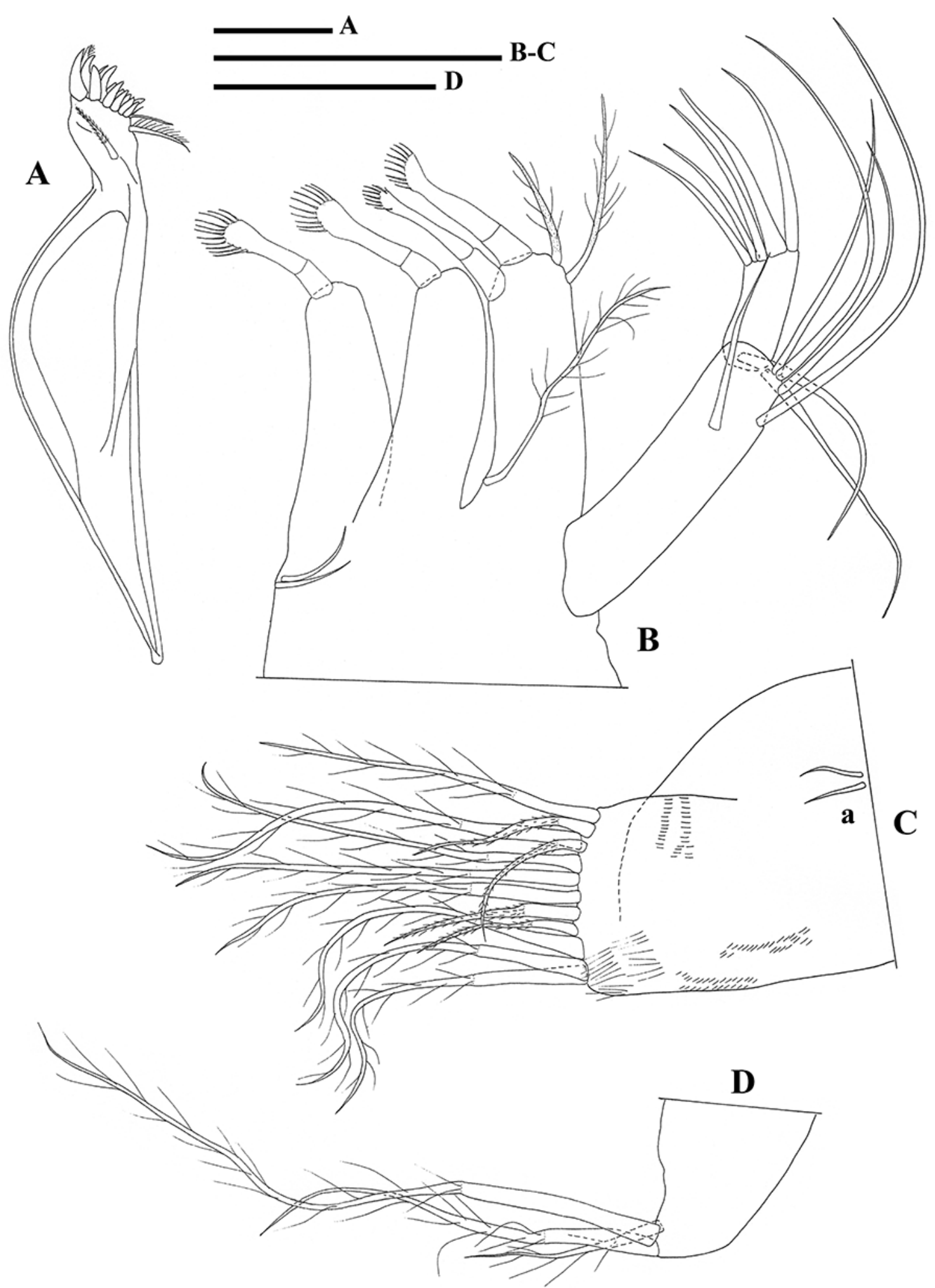

Fig. 3. Thaicypridopsis longispinosa sp. nov., 웅․ A. Md-coxa (MSU-ZOC.257). B. Mx-1 (MSUZOC.264). C. T1 (idem). D. Endopodite of T1 (idem). Scale bars: $50 \mu \mathrm{m}$. 
A1 (Fig. 2A-B). Seven-segmented, first segment with one short dorso-subapical seta (reaching tip of next segment) and two long ventro-apical setae. Second segment slightly wider than long, with one short dorso-apical seta (reaching half of next segment) and Rome organ. Third segment bearing two setae: one long dorso-apical (reaching beyond tip of penultimate segment) and one short ventro-apical setae (reaching slightly beyond half of next segment). Fourth segment with two long dorsal setae and two short ventral setae (both reaching slightly beyond tip of next segment). Fifth segment dorsally with two long setae, ventrally with two (one long, one short) setae, short one reaching slightly beyond tip of next segment. Penultimate segment with four long apical setae. Terminal segment with three (two long, one short) apical setae and long aesthetasc ya, length of aesthetasc ya c. length of last four segments, length of short seta slightly less than half of that of aesthetasc ya.

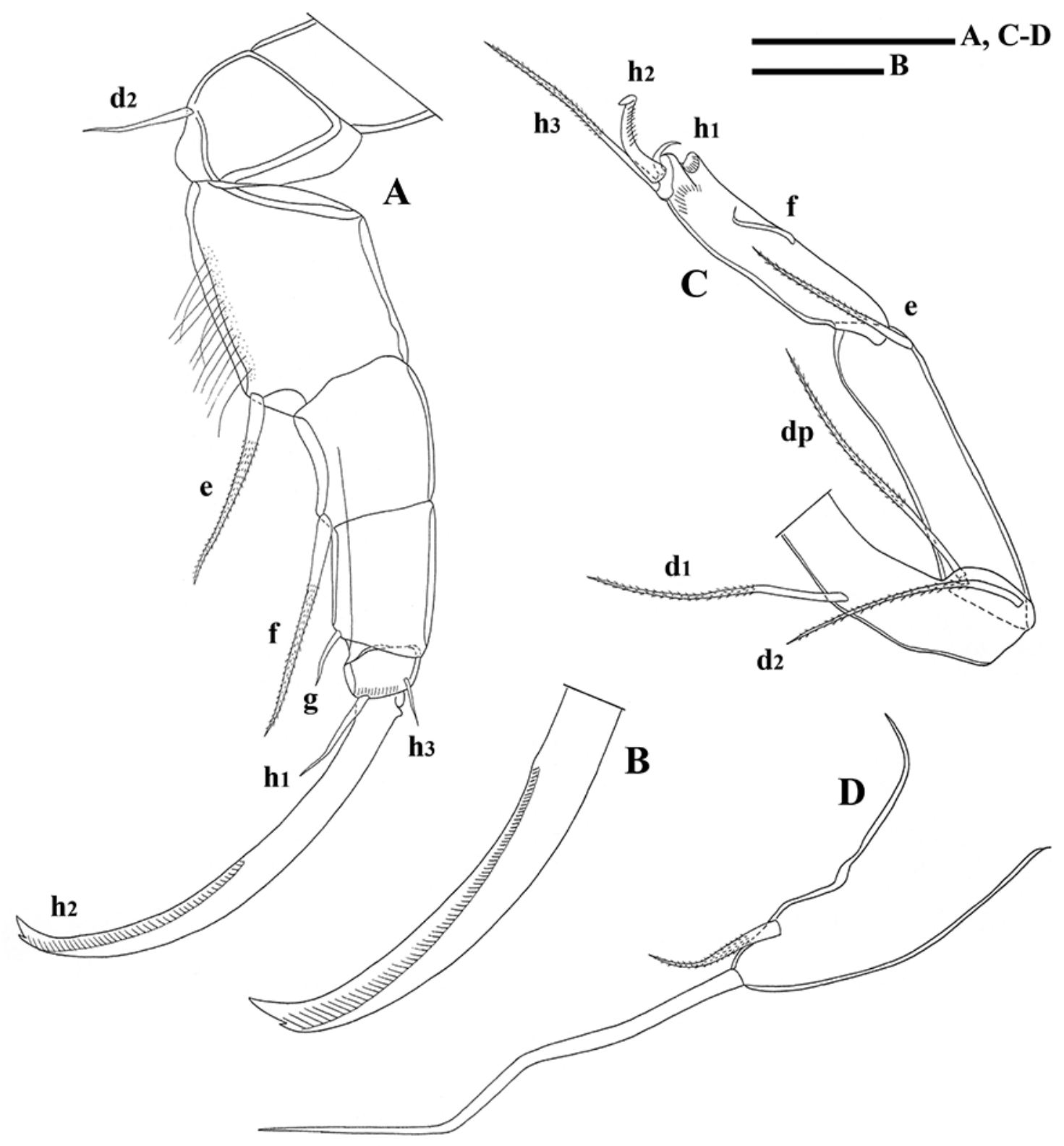

Fig. 4. Thaicypridopsis longispinosa sp. nov., 우. A. T2 (MSU-ZOC.257). B. Distal part of T2 terminal claw (idem). C. T3 (idem). D. CR (MSU-ZOC.264). Scale bars: A, C $=50 \mu \mathrm{m} ; \mathrm{B}, \mathrm{D}=20 \mu \mathrm{m}$. 
A2 (Fig. 2C-E). Basal segment with two proximal setae and one long ventro-apical seta. Exopodite with three (one long, two short) setae, long one reaching slightly beyond half of penultimate segment. First endopodal segment with five very long (reaching far beyond tips of terminal claws) and one short natatory setae, length of the shortest seta reaching three fourth of penultimate segment, aesthetasc $\mathrm{Y}$ long, ventro-apical seta long, extending beyond tip of terminal segment. Penultimate segment undivided, distally with three serrated claws (G1-G3), G1 and G2 large, G2 strongly serrated apically with concave apex, G3 slender claw, aesthetasc y2 long (not reaching tip of terminal segment), z1-z3 setae long, Z1 slightly larger than other z setae, z2 longest (beyond tip of claws G1-G3); this segment medially with two subequally long dorsal setae, four ventral setae of unequal length (t1-t4), one t seta clawlike appearance. Terminal segment distally with two serrated claws (GM and Gm), length of Gm c. $2 / 3$ of that of GM; medially with short g seta and ventral aesthetasc y3, length of aesthetasc y3 c. half of accompanying seta.

MD-PALP (Fig. 2F). First segment with two large setae (S1 and S2), one long and slender seta, and a short, smooth $\alpha$-seta. Second segment dorsally with three unequal long apical setae, shortest seta reaching tip of next segment; ventrally with group of three long hirsute setae, one shorter hirsute seta and plumose, cone-shaped $\beta$-seta with pointed tip. Penultimate segment consisting of three groups of setae: dorsally with group of four unequal, long, subapical setae; laterally with apical $\gamma$-seta and three further apical smooth setae, the former slightly plumose (length c. 2.4 times of terminal segment); ventrally with two subapical setae, one long (reaching beyond tip of terminal segment), one short (c. half of terminal segment). Terminal segment bearing three claws and two shorter setae, largest claw appearing strongly robust with hairy ending.

Mx1 (Fig. 3B). With two-segmented palp, basal segment of palp dorsally with group of six long, unequal apical setae; ventrally with one long subapical seta (reaching slightly beyond tip of terminal segment). Terminal segment elongated (length c. 2 times of width), apically with three claws and two setae. Large bristles on endites claw-like, with hirsute ending and spatula-shaped apex, number of large bristles on first to third endites being 1, 1, 2, respectively. Sideways-directed bristles on first endite short, subequal in length.

T1 (Fig. 3C-D). Protopodite with two unequally short a-setae, b-, c- and d-setae absent, distally with 12 hirsute apical setae of unequal length. Endopodite weakly built palp with one very long, hirsute seta and two unequally shorter apical setae, length of shortest one less than $1 / 3$ of long one.

T2 (Fig. 4A-B). With $\mathrm{d} 2$ seta (d1 absent). Second segment with long e-seta (length c. $2 / 3$ of penultimate segment). Penultimate segment divided, proximal segment bearing long f-seta (reaching beyond tip of terminal segment), distal segment with short apical g-seta (reaching tip of terminal segment). Terminal segment with two (one dorsally, one ventrally) apical h1 and h3 setae (length of the former less than $1 / 3$ of claw, the latter short) and serrated claw (h2) with slightly bifurcated tip, length of h2 longer than that of penultimate segment.

T3 (Fig. 4C). A cleaning limb. First segment with subequal long d1, d2, dp setae. Second segment with long apical e-seta (reaching half of next segment). Third segment with short f-seta (not reaching tip of segment). Terminal segment with an apical pincer and one reflexed subapical seta, length of the latter slightly shorter than that of third segment.

CR (Fig. 4D). Reduced, flagellum-like with triangular base, laterally with short subapical seta, length of long seta c. 1.7 times of that of ramus and c. 3.8 times of that of short subapical seta.

\section{Male}

Unknown. 


\section{Key to genera with LV overlapping $R V$ in the subfamily Cypridopsinae}

1. Respiratory plate of $\mathrm{T} 1 \mathrm{absent}$ Austrocypridopsis McKenzie, 1982

- Respiratory plate of $\mathrm{T} 1$ present

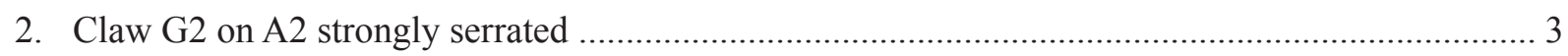

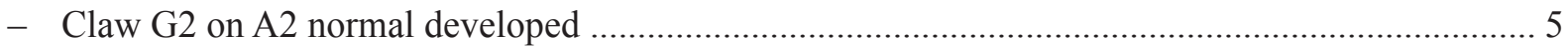

3. Terminal claw of T2 with bifurcate end, large setae on Mx1endites with spatula-shaped apex, valve surface without circular ridges

Thaicypridopsis gen. nov.

- Terminal claw of T2 without bifurcate end, large setae on Mx1 endites without spatula-shaped apex

4. Hinge simple and adont, valve surface without circular ridges

Cabelodopsis Higuti \& Martens, 2012

- Hinge well developed, valve surface with prominent circular ridges Zonocypris Müller, 1898

5. Pincer organ on $\mathrm{T} 3$ absent Neocypridopsis Klie, 1940

- Pincer organ on T3 present 6

6. CR absent in female and male Pseudocypridopsis Karanovic, 1999

- CR present in female 7

7. Carapace elongated, marginal fused zone somewhat broad, A2 natatory setae short Cavernocypris Hartmann, 1964

- Carapace more ovated, marginal fused zone (if present) narrow, mostly A2 natatory setae long .... 9

8. Right prehensile palp with wing-like expansion on terminal segment, A2 aesthetasc Y 2-segmented Tungucypridopsis Victor, 1983

- Right prehensile palp without wing-like expansion on terminal segment, A2 aesthetasc Y 3- or 4-segmented

Cypridopsis Brady, 1867

\section{Discussion}

\section{Morphology and taxonomy}

The subfamily Cypridopsinae, based on the valve overlap, is divided into two groups: the LV overlapping the RV and the RV overlapping the LV. The former group which comprises nine genera, including the new genus, is also united by the cylindrical and elongated shape of the terminal segment of the Mx1palp. However, it should be emphasized that this group is not monophyletic because it includes two tribes: Zonocypridini and Cypridopsini (see Higuti \& Martens 2012). The grouping standing on the valve overlap is merely suitable for the identification key as the valve overlap is primarily the most easily recognized character.

Among the cypridopsine species, the new species seems to resemble the Cypridopsis representatives, but its limbs' morphology is different in many aspects, especially the strongly serrated claw G2 on the A2, the large bristles with spatula-shaped apex on the Mx1-endites and the T2 terminal claw with bifurcate tip. These features of the new species are not found in the Cypridopsis. The presence of a submarginal row of the tubercles on the postero-ventral part of the RVi is a prominent character in the new genus. This aspect leads to the affinity between the new genus and a few other cypridopsine genera, namely Cabelodopsis, Klieopsis, Siamopsis and Zonocypris. At an identical position, the first three genera have septa-like or tiny tubercle(-like) structures (see Martens et al. 1991; Higuti \& Martens 
2012; Savatenalinton 2017), while a submarginal row of prominent tubercles appears in the new genus and Zonocypris costata (Vávra, 1897) (Müller 1898, as Zonocypris madagascarensis). The presence of these tubercles and structures is thus a homologous character. Among these five genera, Thaicypridopsis gen. nov. and $Z$. costata are likely more advanced due to the most well-developed form of tubercles. Thaicypridopsis gen. nov. and Z. costata have the LV overlapping the RV and the obvious tubercles occur on the smaller valve. This is similar to the case of the subfamily Cyprinotinae, where the smaller valve also has tubercles (see, for example, Broodbakker 1983; Martens 1984; Martens \& Wouters 1985; Meisch 2000; Savatenalinton \& Martens 2008). Nevertheless, the position of tubercles is obviously different. They appear between the valve margin and the inner list in $Z$. costata and the new genus whereas in Cyprinotinae, they are on the valve margin. This indicates that these tubercles are not homologous structures in these two groups. Due to the presence of tubercles on the smaller valve and complementary shallow sockets (pits) on the larger valve (see Fig $1 \mathrm{H}, \mathrm{K}-\mathrm{L}$ ), these structures could possibly relate to the valve closure. The septa-like or tubercle-like structures appearing on the larger valve, as in the case of Klieopsis and Siamopsis, would imply that these features seem to display different functions. To date, there are no such tubercles recognized on the LV in the Cypridopsinae.

Based on the morphology of the soft parts, especially the strong serrated claw G2 of the A2, the new genus belongs to the tribe Zonocypridini Higuti \& Martens, 2012 accompanying Zonocypris and Cabelodopsis (see Higuti \& Martens 2012). The strong serration on the claw G2 of the A2 is regular (without an apical cancavity), as seen in Zonocypris species (see, for example, Müller 1898; Rome 1969; Klie 1936, 1944) while in the new genus, the serrated margin is concave apically (see Fig 2C, E). Such irregular serration has not yet been mentioned in the subfamily Cypridopsinae, except for the new genus.

The claws on the terminal segment of the Md-palp are smooth with pointed ends in the cypridopsine genera. The exception occurs in Tanganyikacypridopsis (see Martens 1985), Thermopsis (see Külköylüoğlu et al. 2003) and Thaicypridopsis gen. nov., in which one large claw is apically equipped with a group of hairs. It should be noted that this feature should be used with caution as it would not be illustrated, even if it exists, in many older descriptions.

The morphology of the Mx1-endites in the new genus is remarkable as the large setae (bristles) are apically hirsute and spatula-shaped and they appear on all three endites. These striking setae are indicative and have not been recognized in any cypridopsine genera. Most genera in the Cypridopsinae have large bristles (Zahnborsten) only on the third endite. An exceptional case was encountered in Z. costata, in which large bristles were also found on the second one. However, the ending of the bristles is pointed in. Z. costata, whereas the spatula-shaped ending represents the new genus. The Mx1-endites are known as the feeding apparatus as they possess a number of strong apical setae. In the Cyprididae species, the first two endites are equipped with monomorphic masticatory apical setae with different length, while the heteromorphic setae only occur on the third one, typically exhibiting two large bristles together with the normal setae. The large bristles can be either smooth or serrated apically and their number can be more than two in some genera, such as Oncocypris (see, for example, Green 1973; Rome 1962; Klie 1938, 1939; Savatenalinton 2015). Such qualitative and/or quantitative modification strongly reinforces the masticatory function of the Mx1. In the new genus, based on the morphology of the modified setae on the Mx1-endites, which look like brushes, their function is unlikely restricted to mastication.

The tip of the T2 terminal claw (h2) is slightly bifurcated in Thaicypridopsis gen. nov. It can be easily recognized under medium maginification (c. 100 times). Before the present study, this feature had never been noticed in Cypridopsinae, while it is one of the diagnostic characters of the genus Oncocypris. The morphology of the T2 terminal claw is very slightly different between Thaicypridopsis gen. nov. and Oncocypris. Whereas the outer margin of the claw is slightly sinuated in some Oncocypris, such as O. debundshae (Green 1973), O. euglypha (Rome 1962) and O. rostrata (Savatenalinton 2015), it is 
smooth in the new genus. In Thaicypridopsis gen. nov., the terminal segment of the T3 possesses the pincer organ, which is identical to that of other cypridopsine genera.

As the new genus shares some characters with Oncocypris, this allows to further discuss the taxonomic position of the subfamily Oncocypridinae which has Oncocypris as the type genus. The main characters which keep the subfamily Oncocypridinae in the family Notodromadidae are the presence of the separate eye cups and the four or five large bristles (Zahnborsten) on the third Mx1 endite (for example, see Savatenalinton 2015) whereas the reduced CR seems to place Oncocypridinae in the subfamily Cypridopsinae. One conceivable solution of such a situation is that Oncocypridinae could be the fourth tribe in the subfamily Cypridopsinae. This viewpoint can also be supported by the morphology of the T2 which relates Oncocypris to the cypridopsine genus, Thaicypridopsis gen. nov. In this way, the family Notodromadidae is no longer a polyphyletic group (see Diaz \& Martens 2018).

Consequently, Thaicypridopsis gen. nov. shares some valve and soft part characters mostly with Cabelodopsis, Zonocypris, Klieopsis, Siamopsis and Oncocypris. The distinguishing features of the new genus mentioned above are taxonomically important differences supporting its position as a separate genus within the subfamily Cypridopsinae.

\section{Ecology and distribution}

Thaicypridopsis longispinosa sp. nov. was encountered in reservoirs, lakes, swamps and rivers in the northern and northeastern parts of Thailand. As large populations occur in reservoirs and lakes (Huai Jorakae Mak, Kwan Phayao and Lam Phayom), in which the peripheral zones were densely occupied by aquatic plants, this could be its favorable habitats. The distribution of the new species was wide in the northeastern part while in the northern part it was encountered only in one locality (Kwan Phayao, point 1 in Fig. 5), and there was no record in the central part. It should also be noted that the number of sampling localities from the northeastern part was high with 236 localities from 17 provinces whereas there were 54 localities from 13 provinces in the northern part and three localities from only one province in the central part. At present, T. longispinosa sp. nov. is a rare species in the country as it was found in

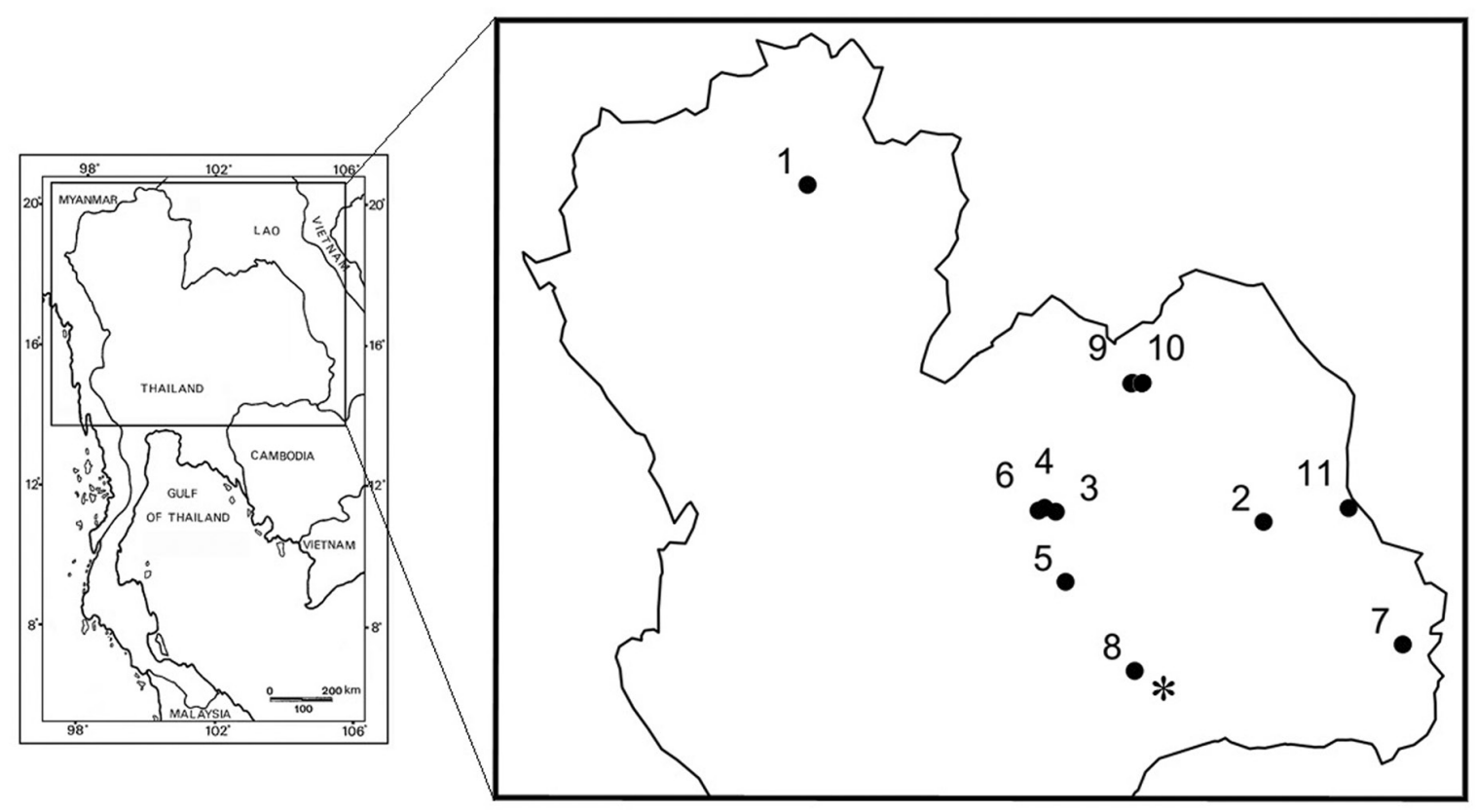

Fig. 5. Distribution map of Thaicypridopsis longispinosa sp. nov. ( $*$ = type locality; numbers $=$ localities mentioned in "Other material examined" section). 
12 of 293 surveyed localities (Fig. 5). The discovery of T. longispinosa sp. nov. is the first record of the Recent representative of the tribe Zonocypridini in Southeast Asia and the Oriental region.

According to the Recent materials and the fossil evidence, there seems to be four lineages within Zonocypridini with respect to the zoogeographical regions, namely Afrotropical, Palaearctic, Neotropic and Oriental lineages. This tribe could originate from the Afrotropical region because it is the center of origin. In addition, Zonocypris which is the most representatives of the tribe, is presently found on the African continent with high endemicity. The Oriental lineage could have evolved from the African ancestor after the Upper Cretaceous due to the fact that the Indian subcontinent was connected to East Africa during the Upper Cretaceous. However, the current data on fossil records show the different phenomenon. The oldest fossils of Zonocypris are from the Cretaceous of Europe, China, India and South America, while the fossils of African Zonocypris, which were recovered from the Miocene sediments, are more recent (Mazzini 2011). Nonetheless, their actual evolutionary pathways should be logically judged after extensive surveys of ostracod fossils are accomplished in these regions.

\section{Acknowledgements}

This work was financially supported by the Thailand Research Fund(TRF, contract number MRG5380256) and Mahasarakham University, Thailand (contract numbers 5405021, 5505004, 5705022 and 5808010). Prof. Dr. Koen Martens (RBINS, Brussels) and an anonymous reviewer provided useful comments. Dr. Akeapot Srifa and Nual-arnong Nakkong (MSU, Thailand) offered technical assistance with the distribution map and the scanning electron micrographs, respectively.

\section{References}

Broodbakker N.W. 1983. The genus Hemicypris (Crustacea, Ostracoda) in the West Indies. Bijdragen tot de Dierkunde 53 (1): 135-157. http://www.repository.naturalis.nl/document/547844

Broodbakker N.W. \& Danielopol D.L. 1982. The chaetotaxy of Cypridacea (Crustacea, Ostracoda) limbs: proposals for a descriptive model. Bijdragen tot de Dierkunde 52 (2): 103-120. http://www.repository.naturalis.nl/document/547666

Diaz A. \& Martens K. 2018. On Argentodromas bellanella gen. nov., sp. nov. (Crustacea, Ostracoda) from a Stream in Northeastern Argentina (South America). Zoological Studies 57: 10. https://doi.org/10.6620/ZS.2018.57-10

Green J. 1973. A new species of Oncocypris (Ostracoda) from a crater lake in west Cameroon. Journal of Zoology 171: 251-256. https://doi.org/10.1111/j.1469-7998.1973.tb02219.x

Higuti J. \& Martens K. 2012. On a new cypridopsine genus (Crustacea, Ostracoda, Cyprididae) from the Upper Parana River Floodplain (Brazil). Zootaxa 3391: 23-38. https://doi.org/10.5281/zenodo.208653

Karanovic I. 2012. Recent Freshwater Ostracods of the World: Crustacea, Ostracoda, Podocopida. Springer-Verlag, Berlin/Heidelberg. https://doi.org/10.1007/978-3-642-21810-1

Klie W. 1936. Ostracoden aus Kamerun. Revue de Zoologie et de Botanique Africaines 28: 287-309.

Klie W. 1938. Ostracoden aus dem belgischen Kongogebiet. Revue de Zoologie et de Botanique Africaines 30: 364-388.

Klie W. 1939. Ostracoden aus dem Kenia-Gebiet, vornehmlich von dessen Hochgebirgen. Internationale Revue der Gesamten Hydrobiologie und Hydrographie 39: 99-161.

Klie W. 1944. Ostracoda. Explor Parc Natl Albert, Mission H Damas 12: 1-62. 
Külköylüoğlu O., Meisch C. \& Rust R.W. 2003. Thermopsis thermophila n. gen. n. sp. from hot springs in Nevada, U.S.A. (Crustacea, Ostracoda). Hydrobiologia 499: 113-123.

https://doi.org/10.1023/A:1026308514466

Martens K. 1984. On the freshwater ostracods (Crustacea, Ostracoda) of the Sudan, with special reference to the Red Sea Hills, including a description of a new species. Hydrobiologia 110: 137-161. https://doi.org/10.1007/BF00025786

Martens K. 1985. Tanganyikacypridopsis gen. n. (Crustacea, Ostracoda) from Lake Tanganyika. Zoologica Scripta 14 (3): 221-230. https://doi.org/10.1111/j.1463-6409.1985.tb00192.x

Martens K. 1987. Homology and functional morphology of the sexual dimorphism in the antenna of Sclerocypris Sars, 1924 (Crustacea, Ostracoda, Megalocypridinae). Bijdragen tot de Dierkunde 57 (2): 183-190.

Martens K., Meisch C. \& Marmonier P. 1991. On Klieopsis gen. nov., with a redescription of Cypridpsis horai Klie, 1927 (Crustacea, Ostracoda). Bulletin van het Koninklijk Belgisch Instituut voor Natuurwetenschappen, Biologie 61: 55-64.

Martens K. \& Savatenalinton S. 2011. A subjective checklist of the Recent, free-living, non-marine Ostracoda (Crustacea). Zootaxa 2855: 1-79.

Martens K. \& Wouters K. 1985. On Hemicypris dentatomarginata (Baird). Stereo-Atlas of Ostracod Shells 12 (23): 127-134.

Mazzini I. 2011. The genus Zonocypris Müller, 1898 (Crustacea, Ostracoda, Cyprididae) from continental Miocene deposits of Central Anatolia (Turkey): palaeoecological and palaeogeographical implications. Joannea Geologie und Paläontologie 11: 124-125.

Meisch C. 2000. Freshwater Ostracoda of Western and Central Europe. In: Schwoerbel J. \& Zwick P. (eds) Süßwasserfauna von Mitteleuropa. 8 (3): 1-522. Spektrum Akademischer Verlag, Heidelberg/ Berlin.

Müller G.W. 1898. Ergebnisse einer zoologischen Forschungsreise in Madagaskar und Ost-Afrika 18891895 von Dr. A. Voeltzkow: Die Ostracoden. Abhandlungen der Senckenbergischen Naturforschenden Gesellschaft 21: 255-296.

Pinto R.L., Rocha C.E.F. \& Martens K. 2005. On new terrestrial ostracods (Crustacea, Ostracoda) from Brazil, primarily from São Paulo State. Zoological Journal of the Linnean Society 145: 145-173.

https://doi.org/10.1111/j.1096-3642.2005.00185.x

Rome D.R. 1962. Exploration hydrobiologique du Lac Tanganyika (1946-1947) 3. Ostracodes. Royal Belgian Institute of Natural Sciences, Brussels.

Rome D.R. 1969. Contribution à l'étude des eaux douces de l'Ennedi: 5. Crustacés, Ostracodes. Bulletin de l'Institut Fondamentale d'Afrique Noire, Series A 31: 1074-1104.

Savatenalinton S. 2015. On three new species of non-marine ostracods (Crustacea: Ostracoda) from Northeast Thailand. Zootaxa 3914 (3): 275-300. https://doi.org/10.11646/zootaxa.3914.3.3

Savatenalinton S. 2017. Siamopsis gen. nov. and five new species of the subfamily Cypridopsinae Kaufmann, 1900 (Crustacea: Ostracoda) from Thailand. European Journal of Taxonomy 384: 1-39. https://doi.org/10.5852/ejt.2017.384

Savatenalinton S. \& Martens K. 2008. Redescription of Hemicypris mizunoi Okubo, 1990 (Crustacea, Ostracoda) from Thailand, with a reassessment of the validity of the genera Hemicypris and Heterocypris. Bulletin van het Koninklijk Belgisch Instituut voor Natuurwetenschappen, Biologie 78: 17-27. 
Savatenalinton S. \& Martens K. 2013. On Callistocypris thailandensis sp. nov. (Ostracoda, Crustacea) from Thailand. Zootaxa 3686 (5): 578-586. https://doi.org/10.11646/zootaxa.3686.5.6

Savatenalinton S. \& Suttajit M. 2016. A checklist of recent non-marine ostracods (Crustacea: Ostracoda) from Thailand, including descriptions of two new species. Zootaxa 4067 (1): 001-034.

https://doi.org/10.11646/zootaxa.4067.1.1

Manuscript received: 10 August 2018

Manuscript accepted: 12 November 2018

Published on: 17 December 2018

Topic editor: Rudy Jocqué

Desk editor: Eva-Maria Levermann

Printed versions of all papers are also deposited in the libraries of the institutes that are members of the EJT consortium: Muséum national d'Histoire naturelle, Paris, France; Meise Botanic Garden, Belgium; Royal Museum for Central Africa, Tervuren, Belgium; Natural History Museum, London, United Kingdom; Royal Belgian Institute of Natural Sciences, Brussels, Belgium; Natural History Museum of Denmark, Copenhagen, Denmark; Naturalis Biodiversity Center, Leiden, the Netherlands; Museo Nacional de Ciencias Naturales-CSIC, Madrid, Spain; Real Jardín Botánico de Madrid CSIC, Spain; Zoological Research Museum Alexander Koenig, Bonn, Germany. 